\title{
Front Matter: Volume 11229
}

, "Front Matter: Volume 11229," Proc. SPIE 11229, Advanced Biomedical and Clinical Diagnostic and Surgical Guidance Systems XVIII, 1122901 (24 March 2020); doi: $10.1117 / 12.2569885$

SPIE. Event: SPIE BiOS, 2020, San Francisco, California, United States 


\section{Advanced Biomedical and Clinical Diagnostic and Surgical Guidance Systems XVIII}

Anita Mahadevan-Jansen

Editor

2-4 February 2020

San Francisco, California, United States

Sponsored and Published by

SPIE

Volume 11229 
The papers in this volume were part of the technical conference cited on the cover and title page. Papers were selected and subject to review by the editors and conference program committee. Some conference presentations may not be available for publication. Additional papers and presentation recordings may be available online in the SPIE Digital Library at SPIEDigitalLibrary.org.

The papers reflect the work and thoughts of the authors and are published herein as submitted. The publisher is not responsible for the validity of the information or for any outcomes resulting from reliance thereon.

Please use the following format to cite material from these proceedings:

Author(s), "Title of Paper," in Advanced Biomedical and Clinical Diagnostic and Surgical Guidance Systems XVIII, edited by Anita Mahadevan-Jansen, Proceedings of SPIE Vol. 11229 (SPIE, Bellingham, WA, 2019) Seven-digit Article CID Number.

ISSN: 1605-7422

ISSN: 2410-9045 (electronic)

ISBN: 9781510632219

ISBN: 9781510632226 (electronic)

Published by

SPIE

P.O. Box 10, Bellingham, Washington 98227-0010 USA

Telephone +1 3606763290 (Pacific Time) · Fax +1 3606471445

SPIE.org

Copyright (c) 2019, Society of Photo-Optical Instrumentation Engineers.

Copying of material in this book for internal or personal use, or for the internal or personal use of specific clients, beyond the fair use provisions granted by the U.S. Copyright Law is authorized by SPIE subject to payment of copying fees. The Transactional Reporting Service base fee for this volume is $\$ 21.00$ per article (or portion thereof), which should be paid directly to the Copyright Clearance Center (CCC), 222 Rosewood Drive, Danvers, MA 01923. Payment may also be made electronically through CCC Online at copyright.com. Other copying for republication, resale, advertising or promotion, or any form of systematic or multiple reproduction of any material in this book is prohibited except with permission in writing from the publisher. The CCC fee code is $1605-$ $7422 / 19 / \$ 21.00$.

Printed in the United States of America by Curran Associates, Inc., under license from SPIE.

Publication of record for individual papers is online in the SPIE Digital Library.

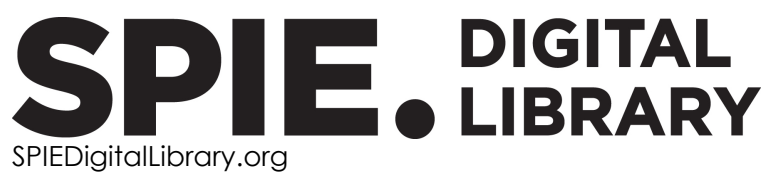

Paper Numbering: Proceedings of SPIE follow an e-First publication model. A unique citation identifier (CID) number is assigned to each article at the time of publication. Utilization of CIDs allows articles to be fully citable as soon as they are published online, and connects the same identifier to all online and print versions of the publication. SPIE uses a seven-digit CID article numbering system structured as follows:

- The first five digits correspond to the SPIE volume number.

- The last two digits indicate publication order within the volume using a Base 36 numbering system employing both numerals and letters. These two-number sets start with $00,01,02,03,04$, 05, 06, 07, 08, 09, 0A, OB ... 0Z, followed by 10-1Z, 20-2Z, etc. The CID Number appears on each page of the manuscript. 


\section{Contents}

$\begin{array}{ll}\text { vii } & \text { Authors } \\ \text { ix } & \text { Conference Committee }\end{array}$

CLINICAL APPLICATIONS OF FLUORESCENCE I

1122905 Deep UV fluorescence scanning microscopy for breast tumor margin detection [1 1229-5]

CLINICAL APPLICATIONS OF FLUORESCENCE II

1122907 Development of a portable imager for intraoperative real-time localization of parathyroid glands [11229-7]

TOMOGRAPHY AND IMAGING

$11229 \mathrm{OL} \quad$ Fiber-free parallel-plane continuous wave breast diffuse optical tomography system [11229-21]

11229 OM System matrix generation for angular domain tomographic reconstruction [1 1229-22]

SPECTROSCOPY AND OTHER TECHNIQUES

$11229 \mathrm{OQ} \quad$ Ultra-stable spectropolarimeter for dermatology [11229-26]

CLINICAL BIOPHOTONICS UNDER REGULATORY EVALUATION

11229 OX Navigating the regulatory pathway for an innovative bionic vision system [1 1229-70]

THERAPEUTICS

$1122911 \quad$ Fiber based black-body radiation thermal sensing for laser interstitial thermal therapy [1 1229-32]

1122912 Evaluation of the optimized surgical illuminant for enhancement of blood oxygen saturation [11229-33] 
IMAGE PROCESSING

1122916 Spatial gradient based segmentation of vessels and quantitative measurement of the inner diameter and wall thickness from ICG fluorescence angiographies [1 1229-37]

1122918 Model for and analysis of intraoperative brain tumor boundary detection based on known spectral signatures of glioblastoma [1 1229-39]

1122919 A 3D resolution and aberration test target for confocal laser endomicroscopy [11229-40]

IMAGING

11229 1D Dual-wavelength photoacoustic imaging for guidance of hysterectomy procedures [1 1229-44]

$11229 \mathrm{lE} \quad$ Photoacoustic image guidance and robotic visual servoing to mitigate fluoroscopy during cardiac catheter interventions [11229-45]

\section{POSTER SESSION}

11229 1G Biomechanical modeling of surgical treatment of unilateral sacral fractures [11229-47]

$11229 \mathrm{1H} \quad$ Recognition of the objects contours in CT and MRI images [11229-48]

$112291 \mathrm{~K}$ Functionality of decision support system for spine and pelvic complex pathology: needs of orthopedic surgeons [1 1229-51]

11229 IL The dependence of Young's modulus of trabecular bony tissue on its density according to computed tomography [11229-52]

11229 iN Development of vessel position estimation system based on pixel-wise refocusing using light field imaging [1 1229-54]

1122910 Aspect ratio as a predictor of cerebral aneurysm rupture [11229-55]

11229 IP Geometric modeling of the heart based on computed tomography [11229-56]

$112291 Q \quad$ Methods of constructing an outline simple closed contour for modeling functional spine unit on CT slice [1 1229-57]

11229 IR Clinical decision support systems: architectural scalability [11229-58]

$112291 \mathrm{U} \quad$ Development of personalized osteotomy technique for the first metatarsal bone [11229-61] 
11229 IY Application of artificial neural network technologies to vertebral segmentation according to CT data [11229-65]

1122912 Analysis of success criteria for surgical treatment of spino-pelvic complex [11229-66] 
Proc. of SPIE Vol. 11229 1122901-6

\section{Downloaded From: https://www.spiedigitallibrary.org/conference-proceedings-of-spie on 26 Apr 2023
Terms of Use: https://www.spiedigitallibrary.org/terms-of-use}




\title{
Authors
}

Numbers in the index correspond to the last two digits of the seven-digit citation identifier (CID) article numbering system used in Proceedings of SPIE. The first five digits reflect the volume number. Base 36 numbering is employed for the last two digits and indicates the order of articles within the volume. Numbers start with 00, 01, 02, 03, 04, 05, 06, 07, 08, 09, OA, OB...0Z, followed by 10-12, 20-2Z, etc.

\author{
Allman, Derek, 1E \\ Assis, Fabrizio, $1 \mathrm{E}$ \\ Beck, Sarah, $1 \mathrm{E}$ \\ Bell, Muyinatu A. Lediju, 1D, 1E \\ Berwanger, Daniel, 16 \\ Beskrovny, Alexander S., 1P, 1Q, 1Y \\ Bessonov, Leonid V., 1K, 1L, 1Q, 1R, 1Y \\ Blaicher, Matthias, 19 \\ Brankov, Jovan G., OM \\ Cha, Jaepyeong, 07 \\ Chen, Ruibo, OL \\ Cheon, Gyeong Woo, 07 \\ Chevrie, K., OX \\ Chrispin, Jonathan, 1E \\ Codd, Patrick, 18 \\ Dellinger, Jean, $0 Q$ \\ Dmitriev, Pavel O., $1 \mathrm{~L}$ \\ Doehring, Todd, 05 \\ Dol, Aleksander V., 1G, 1H, 1O, 1Q \\ Dol, Dmitry, 1Q \\ Dong, Jinxin, $1 \mathrm{E}$ \\ Draman, Cemal, $0 Q$ \\ Emmrich, Amanda, 05 \\ Falkovich, Alexander S., IL, 1Q \\ Fedonnikov, Aleksander S., $1 \mathrm{~K}$ \\ Fisher, Renee, 05 \\ Franz, Paris, 11 \\ Gilat-Schmidt, Taly, 05 \\ Golyadkina, Anastasiya A., 1L, 1P, 1U, 1Z \\ Gonzalez, Eduardo, $1 \mathrm{E}$ \\ Graham, Michelle T., 1E \\ Gubbi, Mardava R., $1 \mathrm{E}$ \\ Haneishi, Hideaki, 12 \\ Hauta-Kasari, Markku, 12 \\ Heinrich, Christian, $O Q$ \\ Hou, Huayu, 1 E \\ Ivanov, Dmitriy V., 1G, 1H, 10, 1 Z \\ Ivanov, Dmitry, $1 Q$ \\ Jorns, Julie, 05 \\ Kazhanov, Igor V., $1 \mathrm{G}$ \\ Kim, Wan Wook, 07 \\ Kireev, Sergey I., 1G, $1 \mathrm{U}$ \\ Kireev, Vladimir S., $1 \mathrm{U}$ \\ Kirillova, Irina $V_{\text {., }} 1 \mathrm{~L}, 1 \mathrm{Z}$ \\ Kolesnikova, Anna S., $1 \mathrm{~K}$ \\ Koos, Christian, 19 \\ Kossovich, Leonid YU., 1K, 1L, 1R, 1 Z \\ Kurabuchi, Yoko, 12 \\ Lemeshkin, Maksim O., $1 Y$
}

\author{
Levchenko, Kristina K., 1G, $1 \mathrm{U}$ \\ $\mathrm{Li}$, Chengyue, OM \\ Lu, Tongtong, 05 \\ Ma, Cheng, OL \\ Ma, Guangshen, 18 \\ Makhankov, Alexei V., 1 Y \\ Manukovsky, Vadim A., IG \\ Mikityuk, Sergey I., $1 G$ \\ Morozov, Konstantin M., IP \\ Naber, Ady, 16 \\ Nahm, Werner, 16, 19 \\ Nakaguchi, Toshiya, 12 \\ Nakano, Kazuya, 12 \\ Nam, So-Hyun, 07 \\ Ning, Bo, 07 \\ Oh, Eugene, 07 \\ Ohnishi, Takashi, 12 \\ Ostrovskiy, Nikolai V., 1P, 1Q, IR \\ Patton, Mollie, 05 \\ Polienko, Asel V., $1 \mathrm{U}$ \\ Protcko, V. G., $1 \mathrm{U}$ \\ Rehbinder, Jean, $\mathrm{OQ}$ \\ Ross, Weston, 18 \\ Rozhkova, Yulia Y., 1K \\ Sheng, Yudong, OL \\ Sim, Sang Jun, $1 \mathrm{~J}$ \\ Steinberg, Gary, 16 \\ Su, Yilun, 19 \\ Takahashi, Hideya, $1 \mathrm{~N}$ \\ Tichaver, Kenneth M., OM \\ Torres, Veronica C., OM \\ Torzynski, Marc, $\mathrm{OQ}$ \\ Trappen, Mareike, 19 \\ Tucker, Matthew, 18 \\ Ulyanov, Vladimir Y., $1 \mathrm{~K}$ \\ Varin, Briséis, $O Q$ \\ Varukhin, Andrey A., IR \\ Veliev, Vugar M., IR \\ Wang, Hui, 11 \\ Wang, Karen C., 1D \\ Wang, Yihan, $\mathrm{OL}$ \\ Wiacek, Alycen, 1D, 1E \\ Wu, Haoqi, OL \\ WU, Harold, ID \\ $\mathrm{Xu}$, Menglu, OL \\ Yamada, Kenji, $1 \mathrm{~N}$ \\ Yamamoto, Kohei, $1 \mathrm{~N}$ \\ Ye, Dong Hye, 05 \\ Yen, Tina, 05
}


Yoshimoto, Kayo, $1 \mathrm{~N}$

Yu, Bing, 05

Zallat, Jihad, $O Q$

Zhao, Jing, OL

Zhu, Shouping, OL

Proc. of SPIE Vol. $112291122901-8$

Downloaded From: https://www.spiedigitallibrary.org/conference-proceedings-of-spie on 26 Apr 2023 Terms of Use: https://www.spiedigitallibrary.org/terms-of-use 


\section{Conference Committee}

Symposium Chairs

Jennifer K. Barton, The University of Arizona (United States)

Wolfgang Drexler, Medizinische Universität Wien (Austria)

Program Track Chairs

Tuan Vo-Dinh, Fitzpatrick Institute for Photonics, Duke University (United States)

Anita Mahadevan-Jansen, Vanderbilt University (United States)

Conference Chair

Anita Mahadevan-Jansen, Vanderbilt University (United States)

Conference Program Committee

Daniel X. Hammer, U.S. Food and Drug Administration (United States)

Dirk J. Faber, Amsterdam UMC (Netherlands)

Christine P. Hendon, Columbia University (United States)

Zhiwei Huang, National University of Singapore (Singapore)

Beop-Min Kim, Korea University (Korea, Republic of)

Muyinatu A. Lediju Bell, Johns Hopkins University (United States)

Hui Min Leung, Massachusetts General Hospital (United States)

Francisco E. Robles, Georgia Institute of Technology \& Emory University School of Medicine (United States)

Tuan Vo-Dinh, Fitzpatrick Institute for Photonics, Duke University (United States)

\section{Session Chairs}

1 Clinical Applications of Fluorescence I

Anita Mahadevan-Jansen, Vanderbilt University (United States)

2 Clinical Applications of Fluorescence II

Laura Marcu, University of California, Davis (United States)

3 OCT Applications

Caroline Boudoux, Polytechnique Montréal (Canada)

4 Deep Learning

Muyinatu A. Lediju Bell, Johns Hopkins University (United States) 
5 Tomography and Imaging

Hui Min Leung, Massachusetts General Hospital (United States)

6 Spectroscopy and Other Techniques

Beop-Min Kim, Korea University (Korea, Republic of)

7 Clinical Biophotonics under Regulatory Evaluation

Daniel X. Hammer, U.S. Food and Drug Administration (United States)

8 Therapeutics

Francisco E. Robles, Georgia Institute of Technology \& Emory University School of Medicine (United States)

$9 \quad$ Image Processing

Anita Mahadevan-Jansen, Vanderbilt University (United States)

10 Imaging

Dirk J. Faber, Amsterdam UMC (Netherlands) 